Nat. Hazards Earth Syst. Sci. Discuss., https://doi.org/10.5194/nhess-2017-262

Manuscript under review for journal Nat. Hazards Earth Syst. Sci.

Discussion started: 21 August 2017

(c) Author(s) 2017. CC BY 4.0 License.

\title{
Potential Impact of Landslide and Debris Flow on Climate Extreme - A Case Study of Xindian Watershed in Taiwan
}

\author{
Shih-Chao WEI ${ }^{1}$, Hung-Ju SHIH ${ }^{2}$, Hsin-Chi LI², Ko-Fei LIU ${ }^{1}$ \\ ${ }^{1}$ Department of Civil Engineering, National Taiwan University, Taipei 10617, Taiwan \\ $5 \quad{ }^{2}$ National Science and Technology Center for Disaster Reduction, New Taipei City 23143, Taiwan \\ Correspondence to: Hsin-Chi LI (hsinchi@ncdr.nat.gov.tw)
}

\begin{abstract}
Sedimentary produced and transported in mountainous area under extreme rainfall by climate change is a challenged issue in recent years, especially in a watershed scale. The scenario approach with coupled simulation by different models could be one of a solution for further discussion under warming climate. With properly model selection, the simulation of projected

10 rainfall, landslide, and debris flow are integrated by fully connection between models. Moreover, a case in Xindian watershed upstream the capital of Taiwan is chose for studying, and two extreme scenarios in late $20^{\text {th }}$ and late $21^{\text {st }}$ century are selected for comparison on changing climate. With sequent simulation, the chain process and compounded disaster can be considered in our analysis. The potential effects of landslides and debris flows are compared between current and future, and the likely impact in selected watershed are discussed under climate extreme. Result shows the unstable sediment volume would enlarge

$1529 \%$ in terms of projected extreme event. The river bed may have strong variation by serious debris flow and increase about $10 \%$ elevation in main channel. These findings also highlight the increasing risk in stable water supply, isolated village effect, and other secondary disaster in this watershed. A practical reference could be provided by some critical information in our result for long-term adapted strategies.
\end{abstract}

\section{Introduction}

20 In recent years, the frequency and magnitude of disaster associated with climate extreme have increased in different evidences. A major concern between climate change and disaster impact becomes important for scientists, policymakers, and the public (IPCC, 2012). Thereby, many researchers has paid their attention to build projected future climate events or explore potential hazard effect of extreme weather.

With the statistics evaluation of World Bank, Taiwan is listed in a high risk disaster area, especially on the slope-land disasters

(Dilley et al., 2005). Therefore, we focus our attention on the slope-land disaster associated with climate change. In addition, a watershed scale is selected to explore the potential effect and to discuss the likely impact of slope-land problem under climate extreme. In climate extreme, previous studies show that the changes in temperature and precipitation will likely affect geohazards on slope land such as landslide or debris flow in each local area (Hsu et al., 2011; Chen et al., 2011). Although temperature can play an important role on slope-land problem such as snowmelt or glacier wasting (Rebetez et al., 1997; 
Nat. Hazards Earth Syst. Sci. Discuss., https://doi.org/10.5194/nhess-2017-262

Manuscript under review for journal Nat. Hazards Earth Syst. Sci.

Discussion started: 21 August 2017

(c) Author(s) 2017. CC BY 4.0 License.

Chiarle et al., 2007; Stoffel et al., 2014), this is not included in this study due to Taiwan is located at low latitude area without snow and glacier in wet season. Therefore, the precipitation becomes the most important factor associated with climate change in Taiwan and it will be the only triggering factor of climate change in the following discussion.

In Taiwan, the major series geo-hazards on slope land can be separate into two parts: landslide, and debris flow. To link these

5 hazards with meteorological properties, the scenario approach is one of the popular way used in recent years. Some of the potential effects on landslide has been explored by given scenarios between current and future (Buma and Dehn, 1998; Collison et al., 2000; Cozier, 2010; Shih et al., 2015). Similarly, the frequency of debris flow has been investigated by projected future rainfall (Rebetez et al., 1997; Stoffel et al., 2014). However, the above-mentioned researches are focus on the relation between meteorological properties of climate change and one of the consequent hazard such as rainfall-landslide, or rainfall-debris flow.

10 But on slope land, different kind of single hazards usually have strong linkage with each other, the chain reaction usually resulted in compound hazards from each single hazards (Chen et al., 2011; Liu et al., 2013). For example, landslide mass is also one of the triggering factor of debris flow (Takahashi, 1981; Iverson, 1997). Therefore, a comprehensive assessment becomes a challenge in the chain reaction between each single hazards on slope land.

By using the given rainfall scenario, the consequent landslide, soil erosion, debris flow, sediment transport, or turbidity in

15 reservoir, etc. can be simulated by different theories or numerical programs so far. However, the theories of different physical phenomena such as sediment production or transport process are discrepancy. Therefore, some researchers start to apply suitable numerical techniques in different physical phenomena, and combine them as a chain by linking a model output to the other model input (Chen et al., 2011; Hsu et al., 2012; Liu et al., 2013; Wu et al., 2016; Fan et al., 2017; Li et al., 2017). With integrated simulation, Chen et al. (2011) has discussed the compound disaster including landslide, debris flow, small-scale

20 floods in past real event. Liu et al. (2013) combined landslide, debris flow, and sediment transport in a catchment scale to simulate the turbidity in the reservoir by using an assumed scenario. Likewise, Wu et al. (2016) also assessed a comprehensive disaster impact including landslide, debris flow, flooding, and coastline disasters in whole watershed. Li et al. (2017) extended this kind of simulation results on further potential loss assessment. The models can be altered in different physical processes but should be properly selected for their discussion issue. Significantly, the chain reaction only can be demonstrated in fully connection between models' output and input.

In the present study, the scenario approach will be used in a selected watershed. With given scenarios, the integrated simulation on landslides and debris flows will be adopted for discussion of potential effect or likely impact under changing climate.

\section{Methodology}

The sediment from production to transport can be regarded as a chain reaction. For example in Taiwan, heavy rainfall triggered

30 by typhoon usually leads to high density of landslides on slope land. When the loose landslide deposit mix with runoff or dammed-lake water, debris flows will occur and flow along gully to downstream. It means the chain reaction of sediment cannot be ignored and should be considered in the discussion of sediment in mountainous area, especially in large scale 
Nat. Hazards Earth Syst. Sci. Discuss., https://doi.org/10.5194/nhess-2017-262

Manuscript under review for journal Nat. Hazards Earth Syst. Sci.

Discussion started: 21 August 2017

(c) Author(s) 2017. CC BY 4.0 License.

discussion. In this process, different physical mechanisms could be simulated by combination of different models (Chen et al., 2011; Hsu et al., 2012; Liu et al., 2013; Wu et al., 2016; Fan et al., 2017; Li et al., 2017) such as rainfall, landslide, debris flow, etc. The detail of each parts will be introduced in the following.

\subsection{Rainfall Scenarios}

5 In recent decades, climate projection for different periods are widely accessible by General Circulation Models (GCM), and it is useful for studying the sequence issues of changing climate at global scale such as frequency of natural hazards, assessment of risk, strategy of adaptation. However, the resolution of GCMs are too course to simulate data for further application in hydrology or agriculture at local scale. For example in typhoon rainfall, the GCM result still cannot describe the small-scale weather patterns in our local area and it also cannot assess in daily or hourly timescale. To link the simulation scale between

10 atmosphere and hydrology, downscaling techniques (statistical or dynamic downscaling) are suggested accomplishing this demand. In Taiwan, these techniques also has been applied in climate projection simulation by Taiwan Climate Change Projection and Information Platform (TCCIP) funded by the Ministry of Science and Technology, and the downscaling dataset are freely provided in the official website of TCCIP.

For the data provided by TCCIP, the Atmospheric General Circulation Model 3.2 (AGCM 3.2) developed by the

15 Meteorological Research Institute (MRI), Japan Meteorological Agency (JMA) is used for global climate simulation at $20 \mathrm{~km}$ horizontal resolution (Mizuta et al., 2012). Meantime, the observed sea surface temperature are considered as lower boundary condition by Coupled Model Intercomparison Project Phase 5 (CMIP5). With the initial state and boundary conditions from the result of MRI-AGCM 3.2, the dynamical downscaling dataset at $5 \mathrm{~km}$ horizontal resolution are simulated by Weather Research and Forecasting Modeling System (WRF) (Skamarock et al., 2008) which is developed by the U.S. National Center

20 for Atmospheric Research (NCAR). Because the underestimate in total rainfall is still found between observations and WRF results, the quantile mapping method is adopted for bias correction in these datasets ( $\mathrm{Su}$ et al. 2016).

Because the climate uncertainties are difficult to assess, the worst case of Representative Concentration Pathway 8.5 (RCP 8.5) scenario issued by IPCC Fifth Assessment Report (IPCC, 2013) is selected to analyse for engineering purpose. According to the RCP 8.5 scenario, the projection rainfall data in late 20th century (1979-2003) and late 21st century (2075-2099) are

25 simulated from TCCIP, and the hourly rainfall at $5 \mathrm{~km}$ horizontal resolution are provided for end user. However, the spatial resolution in $5 \mathrm{~km}$ is still too large for simulation of landslide or debris flow. To satisfy the precision for further discussion, the spatial interpolation from $5 \mathrm{~km}$ to $40 \mathrm{~m}$ is made for selecting scenarios, and used as the input of landslide simulation.

\subsection{Landslide Inventory Simulation}

Potential landslide simulation model is used to evaluate the probability of landslide or assess if it will slide or not. According

30 to different theories, it can be separated into two major branches: statistical approach such as binary regression model (Chang and Chiang, 2009), and physical approach such as slope stability analysis (Baum et al., 2008; Montgomery and Dietrich, 1994). Because the rainfall input in each grid cell are non-homogeneous in space and time. A grid-based model could be practical for 
Nat. Hazards Earth Syst. Sci. Discuss., https://doi.org/10.5194/nhess-2017-262

Manuscript under review for journal Nat. Hazards Earth Syst. Sci.

Discussion started: 21 August 2017

(c) Author(s) 2017. CC BY 4.0 License.
Natural Hazards

and Earth System

Sciences

Discussions

(c) (i)

connection between rainfall and landslide. Therefore, a physical approach, the Transient Rainfall Infiltration and Grid-based Regional Slope-Stability Model (TRIGRS), is selected for assessing landslide area.

The TRIGRS is an inventory of shallow landslide simulation program developed by USGS (Baum et al., 2008), and it has been widely used in several case studies of shallow landslide (Salciarini et al., 2006; Godt et al., 2008; Park et al., 2013; Shih et al.,

5 2015). As TRIGRS is a shallow landslide simulation program, the deep-seated landslide is not available in our discussion.

With infinite slope stability hypothesis, the potential slope failure can be determined by the ratio of resisting basal Coulomb friction to gravitationally induced driving stress. The ratio is called Factor of Safety (FS) and can be expressed as

$F S(Z, t)=\frac{\tan \phi}{\tan \alpha}+\frac{C-\psi(Z, t) \gamma_{w} \tan \phi}{\gamma_{s} d_{L Z} \sin \alpha \cos \alpha}$,

where $\phi$ is soil internal friction; $C$ is cohesion; $\gamma_{w}$ and $\gamma_{s}$ are unit weight of water and soil; $d_{L Z}$ is the depth of the

10 impermeable lower boundary or soil thickness; $\alpha$ is slope angle; $\psi(Z, t)$ is the pore water pressure with vertical soil thickness $Z$ at time $t$, and it is calculated by a linearized solution of one-dimensional Richard's equation (Iverson, 2000; Baum et al., 2008) below

$$
\begin{aligned}
& \psi(Z, t)=[Z-d] \beta \\
& +2 \sum_{n=1}^{N} \frac{I_{n Z}}{K_{Z}} H\left(t-t_{n}\right)\left[D_{1}\left(t-t_{n}\right)\right]^{\frac{1}{2}} \sum_{m=1}^{\infty}\left\{\operatorname{ierfc}\left[\frac{(2 m-1) d_{L Z}-\left(d_{L Z}-Z\right)}{2\left[D_{1}\left(t-t_{n}\right)\right]^{1 / 2}}\right]+\operatorname{ierfc}\left[\frac{(2 m-1) d_{L Z}+\left(d_{L Z}-Z\right)}{2\left[D_{1}\left(t-t_{n}\right)\right]^{1 / 2}}\right]\right\}, \\
& -2 \sum_{n=1}^{N} \frac{I_{n Z}}{K_{Z}} H\left(t-t_{n+1}\right)\left[D_{1}\left(t-t_{n+1}\right)\right]^{\frac{1}{2}} \sum_{m=1}^{\infty}\left\{\operatorname{ierfc}\left[\frac{(2 m-1) d_{L Z}-\left(d_{L Z}-Z\right)}{2\left[D_{1}\left(t-t_{n+1}\right)\right]^{1 / 2}}\right]+\operatorname{ierfc}\left[\frac{(2 m-1) d_{L Z}+\left(d_{L Z}-Z\right)}{2\left[D_{1}\left(t-t_{n+1}\right)\right]^{1 / 2}}\right]\right\}
\end{aligned}
$$

where $d$ is the vertical depth of steady-state water table, $\beta=\cos ^{2} \alpha-\left(I_{Z L T} / K_{S}\right)$, where $K_{S}$ is the saturated hydraulic

15 conductivity and $I_{Z L T}$ is the initial surface flux, $I_{n Z}$ is the surface flux of a given intensity for the $n^{\text {th }}$ time interval (i.e. rainfall input), $D_{1}=D_{0} \cos ^{2} \alpha$, where $D_{0}$ is the saturated hydraulic diffusivity, $N$ is the total number of time intervals, and $H\left(t-t_{n}\right)$ is Heaviside step function. The ierfc is the first integral of complementary error function and can be expressed as $\operatorname{ierfc}(\eta)=\pi^{-1 / 2} \exp \left(-\eta^{2}\right)-\eta \operatorname{erf} c(\eta)$

During the TRIGRS simulation, the FS of each grid is larger than 1, i.e. the infinite slope is stable, in the beginning. With the

20 rainfall and infiltration, the FS will decrease by the increment of pore water pressure. The unstable grid or failure of an infinite slope is occurred once the FS less than 1, and it will be regarded as potential landslide area. With soil thickness $d_{L Z}$ in each unstable grid, the potential landslide volume could be further evaluated for debris flow simulation input.

\subsection{Debris Flow Simulation}

For debris flow assessment, numerical simulation is the most popular approach in recent years (O'Brien et al., 1993; Hutter et

al., 1995; Hungr et al., 1995; Sassa et al., 2004; Liu and Huang, 2006; Nakatani et al., 2008; Armanini et al., 2009; Christen et at., 2010). Although different kind of numerical programs were developed from different theories, the governing equations 
Nat. Hazards Earth Syst. Sci. Discuss., https://doi.org/10.5194/nhess-2017-262

Manuscript under review for journal Nat. Hazards Earth Syst. Sci.

Discussion started: 21 August 2017

(c) Author(s) 2017. CC BY 4.0 License.
Natural Hazards

and Earth System

Sciences

Discussions

(c) $\underset{\mathrm{BY}}{\mathrm{P}}$

comes from mass and momentum conservation. With practical application of input, these models could be divided into two branches such as hydrological-based with a calibrated hydrograph at a specified inflow location (O'Brien et al., 1993; Nakatani et al., 2008; Armanini et al., 2009), and geologic-based with initial mass distributed on its source area (Hutter et al., 1995; Hungr et al., 1995; Sassa et al., 2004; Liu and Huang, 2006; Christen et at., 2010). To link debris flow simulation with landslide

5 result, a geologic-based model is more useful for application. In this study, we apply Debris-2D (Liu and Huang, 2006) for simulating the debris-flow transport process.

The Debris-2D has been widely applied in real debris-flow cases (Liu et al., 2009, Tsai et al., 2011, Wu et al., 2013). In Debris$2 \mathrm{D}$, the debris flow is treated as a single phase non-Newtonian fluid. A three-dimensional constitutive relation generalized by Julien and Lan (1991) is adopted in this model and the depth-averaged governing equations to the leading order (Liu \& Huang,

10 2006) are

$\frac{\partial H}{\partial t}+\frac{\partial(u H)}{\partial x}+\frac{\partial(v H)}{\partial y}=0$

$\frac{\partial(u H)}{\partial t}+\frac{\partial\left(u^{2} H\right)}{\partial x}+\frac{\partial(u v H)}{\partial y}=-g H \cos \theta\left(\frac{\partial B}{\partial x}+\frac{\partial H}{\partial x}\right)+g H \sin \theta-\frac{1}{\rho} \frac{\tau_{0} u}{\sqrt{u^{2}+v^{2}}}$,

$\frac{\partial(v H)}{\partial t}+\frac{\partial(u v H)}{\partial x}+\frac{\partial\left(v^{2} H\right)}{\partial y}=-g H \cos \theta\left(\frac{\partial B}{\partial y}+\frac{\partial H}{\partial y}\right)-\frac{1}{\rho} \frac{\tau_{0} v}{\sqrt{u^{2}+v^{2}}}$,

where $H$ is flow depth; $B$ is bed topography; $u$ and $v$ are depth-averaged velocities in $x$-and $y$-direction respectively; $\theta$

15 is bed slope; $\tau_{0}$ and $\rho$ are debris-flow yield stress and density; $g$ is gravitational acceleration. Without consideration of bottom erosion and deposition effect, the yield stress becomes the dominant bottom stress. By applying Eq. (3) (5), the $H$, $u$, and $v$ can be calculated with an initial stationary debris pile $H$. In addition, all debris flow obeys a starting condition (Liu and Huang, 2006) and only flows once pressure and gravitational effects exceed the yield stress effect.

Based on Eq. (3) (5), the input data are topography $B$, initial debris flow depth $H$, and yield stress $\tau_{0}$. The topography is

20 decided by Digital Elevation Model (DEM) which is the same as landslide simulation. Because the climate extreme is considered, there would be enough rainfall to initialize all dry debris produced from landslide. With the landslide area simulated by TRIGRS and its corresponding soil thickness $d_{L Z}$ in each grid calls, the initial debris flow depth $H$ can therefore be determined by the following relation (Liu and Huang, 2006; Liu et al., 2009)

$H=d_{L Z} / C_{d \infty}$

25 where the $C_{d \infty}$ is equilibrium concentration (Takahashi, 1981) below

$C_{d \infty}=\frac{\rho_{w} \tan \theta}{\left(\rho_{s}-\rho_{w}\right)(\tan \phi-\tan \theta)}$,

where $\rho_{w}$ and $\rho_{s}$ are density of water and sediment; $\phi$ is internal friction angel; $\theta$ is average creek bottom slope. 
Nat. Hazards Earth Syst. Sci. Discuss., https://doi.org/10.5194/nhess-2017-262

Manuscript under review for journal Nat. Hazards Earth Syst. Sci.

Discussion started: 21 August 2017

(c) Author(s) 2017. CC BY 4.0 License.

\subsection{Integrated Simulation Process}

With above introduction, an integrated simulation process is built as shown in Fig. 1. According to Fig. 1, rainfall events are simulated by MRI-AGCM3.2, downscaled with WRF, and modified with bias correction. To accomplish the research demand on discussion of climate change, two extreme rainfall scenarios from different periods are collected to compare the difference.

5 With rainfall input and other corresponding parameters, the potential landslide area are simulated by TRIGRS and the landslide inventory maps are made for different scenarios. Because the sediment production during a rainfall event is dominated by landslide mass (Hsu et al., 2012), the soil erosion on slope land is ignored in our discussion. Under extreme rainfall and loose landslide mass, we assume sediment will transport by debris flow from upstream catchment. Accordingly, all landslide mass is considered as the input of debris flow and simulated by Debris-2D. The chain effect may be reacted by this integrated

10 simulation in a watershed point of view and the compounded disaster between current and future can be compared in terms of climate change.

\section{Case Study: Xindian Watershed}

\subsection{Study Area}

Xindian watershed is located in the upstream of capital, Taipei, northern Taiwan. Xindian river is one of the three major

15 tributaries into the Tamsui River and it is one of the main source of drinking water for Taipei city and New Taipei city. According to the Taipei City Running Water Center, over 4 million Taipei residents obtain 97\% of their drinking water from this river. The main tributary of Xindian river are Nanshi river and Beishi river, as shown in Fig. 2. Comparing this two tributaries, the geological condition in Nanshi River catchment is more fracture than Beishi river catchment, and the historical landslide are concentrated along Nanshi River (Wei et al., 2015, Wu et al., 2016). So we focus our attention on the Nanshi

20 River catchment and ignore the catchment beyond Feitsui reservoir.

In Fig. 2, the whole study area is 49,000 ha. The villages are major along Nanshi river such as Wulai, Xinxian, and Fushan including 2716, 622, and 739 inhabitants, respectively. In this area, it can be found the high variation of elevation, and can be seen lots of canyon-like topography along the bank of Nanshi river. The study area are mainly located in Tatungshan Formation (Tt), Szeleng Sandstone (Em), Kangkou Formation (Kk), Mushan Formation (Ms), Tsuku Formation (Tu), and its content are

25 major from sand stone, argillite, slate, shale, siltstone. The age of geological setting are between Holocene and Eocene. Lots of folds and faults are distributed in this area.

Because soft and fractured geological condition in Nanshi river catchment, the geo-disaster and its sediment problem becomes an important issue in this area (Wei et al., 2015; Wu et al., 2016). For example, the Typhoon Soudelor during $7^{\text {th }}$ Aug. and $9^{\text {th }}$ Aug. in 2015 has brought heavy rainfall in this area. The maxima accumulated precipitation reached 792 mm at Fushan 30 meteorological station. Besides, the maxima accumulated rainfall in $3 \mathrm{hrs}, 6 \mathrm{hrs}$, and 12 hrs at Fushan meteorological station were beyond 200-years return period (Wei et al., 2015), and came to $253 \mathrm{~mm}, 442 \mathrm{~mm}$, and $655 \mathrm{~mm}$, respectively. The maxima 
Nat. Hazards Earth Syst. Sci. Discuss., https://doi.org/10.5194/nhess-2017-262

Manuscript under review for journal Nat. Hazards Earth Syst. Sci.

Discussion started: 21 August 2017

(C) Author(s) 2017. CC BY 4.0 License.
Natural Hazards

and Earth System

Sciences

Discussions

(c) (i)

intensity in this event got up to $95 \mathrm{~mm} / \mathrm{hr}$ and the average intensity on $8^{\text {th }}$ Aug., 2015 also reached $80 \mathrm{~mm} / \mathrm{hr}$. Lots of landslide and debris flow were triggered by this short period and high intense rainfall. The total landslide volume was estimated as $9.8 \times 10^{6} \mathrm{~m}^{3}$ and the sediment delivery rate was evaluated about $40.98 \%$ in Nanshi river. (Wu et al., 2016). The regional landslide disasters induced the closure of roads and the debris flow from tributary also increased the concentration in the

5 Nanshi river. According to Taipei Water Department, the peak turbidity came to 39,300 NTU at 08:00, $8^{\text {th }}$ Aug., 2015 and it took 42 hours to reduce to 3,000 NTU (the limit of turbidity of water treatment plant). Therefore, the stable water supply was broken and the quality of water was also influenced during $9^{\text {th }}$ Aug. and $12^{\text {th }}$ Aug, 2015 (4 days) in Taipei area.

As mentioned above, the influence of sediment related hazard not only occurs in Xindian watershed but affects in downstream Taipei city. For long-term city planning aspect, it is urgent to realize the whole situation and establish adapted strategies under

10 climate change. Accordingly, we will apply the above-mentioned integrated simulation to assess the potential impact in this watershed.

\subsection{Extreme Rainfall Scenarios}

The projection rainfall in late $20^{\text {th }}$ century (1979-2003) and late $21^{\text {st }}$ century (2075-2099) collected from TCCIP are chose for comparison in our study area. Because the bias correction with observation is conducted in previous research (Su et al., 2016),

15 we will directly use these data without calibration. With engineering purpose, the worst cases (i.e. the rank 1 rainfall event) in the late $20^{\text {th }}$ and $21^{\text {st }}$ century are selected for comparison and we will use scenario 1 and scenario 2 for abbreviation. The accumulated rainfall distribution are shown in Fig. 3a. With representative data at Fushan meteorological station, the maxima accumulated rainfall are $911.4 \mathrm{~mm}$ in $61 \mathrm{hr}$ and $1531.1 \mathrm{~mm}$ in $40 \mathrm{hr}$, and the maxima intensity comes to $49.7 \mathrm{~mm} / \mathrm{hr}$ and 125.8 $\mathrm{mm} / \mathrm{hr}$, respectively. For both scenarios, the temporal and spatial resolution are in $1 \mathrm{hr}$ and $5 \mathrm{~km}$, respectively. The spatial interpolation from $5 \mathrm{~km}$ to $40 \mathrm{~m}$ is adopted for landslides and debris flows simulation purpose.

\subsection{Landslide Inventory Simulation}

Based on Eq. (1) and Eq. (2), the TRIGRS input data of each grid cell is separated into four parts: rainfall intensity, topographic information, soil parameters, and hydraulic parameters. The rainfall intensity $I_{n z}(\mathrm{~mm} / \mathrm{hr})$ presented in previous section are directly used. The topographic information, slope $\alpha$ and flow aspect, are derived from DEM at $40 \mathrm{~m}$ resolution. The soil

25 parameter and hydraulic parameters such as $C, \phi, \gamma_{s}, K_{S}$, and $D_{0}$ could be calibrated by past events or cited from past investigation (Central Geological Survey, 2010). The soil thickness $d_{L Z}$ is calculated by empirical slope-depth relation (Khazai and Sitar, 2000; National Science and Technology Center for Disaster Reduction, 2011). Without considering antecedent precipitation, we assume the initial depth of steady-state water table $d$ is the same as soil thickness $d_{L Z}$ and the initial infiltration rate for soil is $10^{-8}(\mathrm{~m} / \mathrm{s})$ (Chen et al., 2005).

30 Because the parameters, $C, \phi, \gamma_{s}, K_{S}$, and $D_{0}$ are subject to geology, the Modified Success Rate (MSR) (Huang and Kao, 2006; Shih et al., 2015) is introduced for calibration and validation with different geologic zones, as shown below 
Nat. Hazards Earth Syst. Sci. Discuss., https://doi.org/10.5194/nhess-2017-262

Manuscript under review for journal Nat. Hazards Earth Syst. Sci.

Discussion started: 21 August 2017

(c) Author(s) 2017. CC BY 4.0 License.
Natural Hazards

and Earth System

Sciences

Discussions

(c) $\underset{\mathrm{BY}}{\mathrm{Br}}$

$\operatorname{MSR}(\%)=\frac{1}{2} \frac{N_{1}}{N_{1}+N_{2}}+\frac{1}{2} \frac{N_{4}}{N_{3}+N_{4}}$.

$N_{1}$ and $N_{2}$ denotes the area of $F S<1$ and $F S>1$ for those historical landslide area, respectively. Likewise, $N_{3}$ and $N_{4}$ presents the area of $F S<1$ and $F S>1$ for those historical non-landslide area. The success rate of landslide and non-landslide can be both specified in Eq. (8). The unit of $N_{1} \sim N_{4}$ is calculated by slope-unit. A success prediction is defined while MSR >

$570 \%$. With the objective function, MSR, the parameters in each zones could be optimized by the rainfall events provided by Central Weather Bureau and historical landslide data provided by Central Geological Survey. However, the historical landslide data are only updated by year, the union of representative rainfall events in each year are used for calibration. The calibrated MSR results from 2008 to 2012 are between $84 \%$ and 88\%, and the calibrated parameters are shown in Table 1. By these parameters, the landslide of typhoon Soudelor in 2015 was validated in a good agreement with $M S R=91 \%$.

10 During simulation, the potential landslide areas are increasing as accumulated rainfall with a time delayed. The growing rate of accumulated landslide ratio in scenario 2 is faster than in scenario 1 due to the effect of rainfall intensity. The stable time with maxima accumulated landslide ratio for scenario 1 and scenario 2 are within $65 \mathrm{hrs}$ and $40 \mathrm{hrs}$, respectively. With potential landslide area $(\mathrm{FS}<1)$ and its soil thickness $d_{L Z}$ in each grids, the landslide inventory maps are shown as Fig. 3b, and used for debris flow simulation.

\section{$15 \quad 3.4$ Debris Flow Simulation}

In Debris-2D simulation, the input data could be separated into three parts: topography (DEM), initial debris-flow mass, and yield stress. For initial debris flow mass, it is calculated by landslide inventory maps with Eq. (6) and (7). Because debris flows are triggered by an extreme rainfall and loose landslide mass, all landslide mass is assumed to be transformed as initial debrisflow mass. Moreover, the high concentration is considered to be occurred, and the maxima $C_{d \infty} \leq 0.603$ (Liu and Huang 2006;

20 Liu et al. 2009) is used for practical estimation in Eq. (6) and (7). However, we cannot predict when the debris flow will occur after slope failure, so the beginning of debris flows are assumed in the same starting time. For yield stress, it is calibrated by plan test (Liu \& Huang 2006) with several samples and the value of $800 \mathrm{~Pa}$ is used for simulation.

The final flow depth of debris flows in both scenarios are shown in Fig. 3c. For both scenarios, the upstream Hapen river debris flows cannot transport to downstream due to the meandering creek. The landslide along the downstream Hapen river and

25 Daluolan river are major deposited before the junction of Zhakong river, Daluolan river, and Happen river. The contribution of flow depth from Daluolan river and Happen river are insusceptible for the debris flow of Zhakong river or Nanshi river. The front of Zhakong river debris flow deposits before a sharp turn in the upstream of Nanshi river in scenario 1, but it reaches the tail of Nanshi river debris flow in scenario 2. The Nanshi river debris flows are deposited before the junction of Nanshi river and Tonghou river. 
Nat. Hazards Earth Syst. Sci. Discuss., https://doi.org/10.5194/nhess-2017-262

Manuscript under review for journal Nat. Hazards Earth Syst. Sci.

Discussion started: 21 August 2017

(c) Author(s) 2017. CC BY 4.0 License.
Natural Hazards

and Earth System

Sciences

Discussions

\section{Result and Discussion}

\subsection{Potential Effect on Natural Hazards}

In this integrated simulation process, the top 1 rainfall events of the worst RCP 8.5 climate scenario are selected for initial input. So the discussion leads to the influence of climate extreme and the comparison of different extreme scenarios. With

5 these rainfall scenarios, the maxima error of landslide area simulated by TRIGRS could be estimated as 16\% because the MSR are between $84 \%$ and $91 \%$ (see Table 1). Moreover, the empirical landslide depth is the input of TRIGRS and it is included in the MSR validation. Therefore, we can simply use the error of landslide area to estimate the error of landslide volume, even though the surveyed data of landslide volume is not available. For debris flow, the source landslide volume is the most sensitive parameter in Debris-2D simulation, and the volume uncertainty in $20 \%$ could be resulted in $2.76 \%$ variation on its deposition

10 front (Tsai et al., 2011). So the uncertainty of deposition front could be roughly estimated as $2.2 \%$ in selected rainfall scenarios. In these two scenarios, the grid-averaged maxima accumulated rainfall are $852.56 \mathrm{~mm}$ in $61 \mathrm{hr}$ and $1255.14 \mathrm{~mm}$ in $49 \mathrm{hr}$, and the grid-averaged maxima accumulated rainfall in $24 \mathrm{hr}$ comes to $484.84 \mathrm{~mm}$ and $1085.05 \mathrm{~mm}$, respectively. Comparing these two scenarios, we found the grid-averaged accumulated rainfall increase $402.58 \mathrm{~mm}$ but the duration decrease $12 \mathrm{hr}$. Based on scenario 1 , the increment of grid-averaged accumulated rainfall and decrement of duration between these two scenarios are

$1547.22 \%$ and $19.67 \%$, respectively.

By using these rainfall scenarios, the landslide area in both scenarios are simulated as $1.67 \times 10^{7} \mathrm{~m}^{2}$ and $2.14 \times 10^{7} \mathrm{~m}^{2}(3.42 \%$ and $4.37 \%$ of the whole watershed), respectively. With empirical slope-depth relation, the landslide volume are estimated as $7.12 \times 10^{7} \mathrm{~m}^{3}$ and $9.19 \times 10^{7} \mathrm{~m}^{3}$. The total debris flow volume transformed by Eq. (11) are $1.18 \times 10^{8} \mathrm{~m}^{3}$ and $1.52 \times 10^{8} \mathrm{~m}^{3}$. Based on scenario 1, the increment of landslide area, landslide volume, and debris flow volume between these two scenarios

20 are $28.14 \%, 29.07 \%$, and $28.81 \%$, respectively.

In debris flow simulation, the major accumulation are deposited along Nanshi river and Zhakong river, and the longitudinal profile of accumulation for both scenarios are shown in Fig. 4. In Fig. 4, the part within and beyond $15 \mathrm{~km}$ belongs to Nanshi river and Zhakong river, and its corresponding average bed slope are $16.85(\mathrm{~m} / \mathrm{km})$ and $31.96(\mathrm{~m} / \mathrm{km})$, respectively. Because the mild slope alone river bed, the landslide along river bank are directly accumulated on its foot area, and the debris flow

25 from tributary are decelerated and deposited as well. The abundant sediment results in strong variation of river geomorphology in both scenarios. By comparing these two scenarios, the average river bed elevation increase $12.32 \%$ on Nanshi river $(0 \sim 15$ $\mathrm{km})$ and $7.74 \%$ on Zhakong river (15 25 km).

\subsection{Likely Impact on Compounded Disaster}

In this study, the worst cases of projected events are selected for discussion of climate extreme and environmental variation.

30 Therefore, the simulation results are not enough and not suitable for doing local risk assessment in each village or tribe. However, the extreme scenarios may provide some critical information and reliable impact in terms of a whole watershed view. So the compounded disaster and its sequent impact are discussed in a regional level here. 
Nat. Hazards Earth Syst. Sci. Discuss., https://doi.org/10.5194/nhess-2017-262

Manuscript under review for journal Nat. Hazards Earth Syst. Sci.

Discussion started: 21 August 2017

(C) Author(s) 2017. CC BY 4.0 License.

The catastrophic slope-land hazard are occurred under extreme rainfall events no matter which scenario we considered. The large amount sedimentary material is supposed to be produced by landslide and to be transported by debris flow or mud flow with sufficient water. The average accumulated rainfall of scenario 1 and scenario 2 are 1.55 and 2.28 times as heavy as Typhoon Soudelor, and the estimated landslide volume in scenario 1 and scenario 2 are 7.26 and 9.37 times as large as Typhoon

5 Soudelor. From the experience of Typhoon Soudelor in 2015, the high turbidity is believed to be occurred in downstream of Nanshi river during our scenarios and the stable water supply will be broken at last three weeks if no measures are taken for prevention.

Between $2 \mathrm{~km}$ and $4 \mathrm{~km}$ in Fig. 4, the landslide along the right bank of Nanshi river are directly block the river and gradually become a dam within $4 \mathrm{~km}$. The front of debris flow are stop at $0 \mathrm{~km}$ in both scenarios, as shown in reach a of Fig. 4 . The

10 downstream Wulai Village would be exposed in a high risk of flooding and dam breaking after debris flow. For Xinxian Village in reach b of Fig. 4, all village are not covered by debris flow. Although there are two potential debris flow torrents at $4.5 \mathrm{~km}$ and $5 \mathrm{~km}$ (downstream and upstream of Xinxian Village) listed by Soil and Water Conservation Bureau in Taiwan, the debris flows here are insusceptible due to past effort of countermeasure. Between $6 \mathrm{~km}$ and $9 \mathrm{~km}$ in reach c of Fig. 4, the landslide along the left bank of Nanshi river causes the road closure in both scenarios. Because it is the only way to reach

15 Fushan Village, the isolated effect would be forced to happen once the road closure occurs. In reach d of Fig. 4, the Fushan Village are also covered by landslide. Therefore, the residents in Fushan Village should be forcibly retreated before the events. As the accumulation in Fig. 4, a sequence dammed lake may occur along Nanshi river and Zhakong river after the extreme event like our scenarios. The secondary disasters by alluvium along river should be continuously concerned after event such as high turbid river water, stream-triggered debris flow, dam breaking torrent, etc.

\section{Conclusion}

With extreme climate projected scenarios, we proposed an integrated physical simulation process to analyse the potential effect or likely impact of landslides and debris flows in a watershed point of view. The Xiandian watershed upstream capital of Taiwan is selected for discussion.

Thanks to TCCIP platform, two extreme rainfall scenarios in late $20^{\text {th }}$ century (1979-2003) and late $21^{\text {st }}$ century (2075-2099)

25 simulated by MRI-AGCM 3.2 and downscaled with WRF are collected for landslide simulation. The potential landslide area are simulated by the TRIGRS model and the parameter in TRIGRS are calibrated and validated by past events. With potential landslide area, the landslide volume is estimated by empirical slope-depth relation. Than the catastrophic debris flows are considered to occur under the extreme rainfall and large amount of landslide volumes, and simulated by Debris-2D model. In this simulation process, the uncertainty of landslide volume and debris flow deposition front are roughly estimated as $16 \%$ and $30 \quad 2.2 \%$.

There is no surprise that landslide volume, debris flow volume, and river bed elevation are increased in an increment of accumulated rainfall trigging by climate change. For comparison of these two scenarios, the grid-averaged accumulated rainfall 
Nat. Hazards Earth Syst. Sci. Discuss., https://doi.org/10.5194/nhess-2017-262

Manuscript under review for journal Nat. Hazards Earth Syst. Sci.

Discussion started: 21 August 2017

(c) Author(s) 2017. CC BY 4.0 License.
Natural Hazards

and Earth System

Sciences

Discussions

(c) (i)

increase $47.22 \%$ but the duration decrease $19.67 \%$. With increasing precipitation, the estimated landslide volumes and debrisflow volumes are in an increment of $29.07 \%$ and $28.81 \%$, respectively. The landslide along river bank and the tributary debris flow also cause a serious increment of river bed. The average raised ratio of river bed along Nanshi and Zhakong river are $12.32 \%$ and $7.74 \%$, respectively.

5 In Xindian Watershed, the possible disasters leads to the influence of water supply, isolated effect of tribe, and increasing risk of secondary disasters. With our practical assessment, the loss of each disasters and its corresponding countermeasures could be further examined or quantified (Liu et al. 2009). The policy-making and the long term strategy in different aspect might be made thereafter.

\section{Acknowledgments}

10 This research was supported by the Ministry of Science and Technology of Taiwan under MOST 105-2625-M-865-001. The CERG-C program of the University of Geneva is thanked for providing the expertise to carry out this project.

\section{References}

Armanini, A., Fraccarollo, L., and Rosatti, G.: Two dimensional simulation of debris flows in erodible channels, Computers \& Geosciences, 35, 993-1006, 2009.

15 Buma, J., and Dehn, M.: A method for predicting the impact of climate change on slope stability, Environmental Geology, 35, 190-196, 1998.

Baum, R. L., Savage, W. Z., and Godt, J. W.: TRIGRS - A Fortran program for transient rainfall infiltration and grid-based regional slope-stability analysis Version 2.0. U.S. Geological Survey (Open-file Report 2008-1159), 2008.

Central Geological Survey: Research on Application of the Investigation Results for the upstream Watershed of Flood-Prone

20 Area. (3/3), Central Geological Survey, Taiwan, 2010.

Chang, K. T., and Chiang, S. H.: An integrated model for predicting rainfall-induced landslides, Geomorphology, 105, 366$373,2009$.

Chen, C. Y., Chen, T. C., Yu, F. C., and Lin, S. C.: Analysis of time-varying rainfall induced landslide, Environmental Geology, 48(4-5), 466-479, 2005.

25 Chen, Y. S., Kuo, Y. S., Lai, W. C., Tsai, Y. J., Lee, S. P., Chen, K. T., and Shieh, C. L.: Reflection of Typhoon Morakot The Challenge of Compound Disaster Simulation, J. Mt. Sci., 8: 571-581, 2011.

Chiarle, M., Iannotti, S., Mortara, G., and Deline, P.: Recent debris flow occurrences associated with glaciers in the Alps, Global Planet Change, 56, 123-136, 2007.

Christen, M., Kowalski, J., and Bartelt, P.: RAMMS: Numerical simulation of dense snow avalanches in three-dimensional 
Nat. Hazards Earth Syst. Sci. Discuss., https://doi.org/10.5194/nhess-2017-262

Manuscript under review for journal Nat. Hazards Earth Syst. Sci.

Discussion started: 21 August 2017

(c) Author(s) 2017. CC BY 4.0 License.
Natural Hazards

and Earth System

Sciences

Discussions

(c) (i)

Collison, A., Wade, S., Griffiths, J., and Dehn, M.: Modelling the impact of predicted climate change on landslide frequency and magnitude in SE England, Eng. Geol., 55, 205-218, 2000.

Crozier, M. J.: Deciphering the effect of climate change on landslide activity: A review, Geomorphology, 124, 260-267, 2010. Dilley, M., Chen, R. S., Deichmann, U., Lerner-Lam, A. L., Arnold, M., Agwe, J., Buys, P., Kjekstad, O., lyon, B., and Yetman,

5 G.: Natural Disaster Hotspots-A Global Risk Analysis, The World Bank, Hazard Management Unit, Washington D.C., 2005.

Fan, L., Lehmanna, P., McArdell, B., and Or, D.: Linking rainfall-induced landslides with debris flows runout patterns towards catchment scale hazard assessment, Geomorphology, 280, 1-15, 2017.

Godt, J. W., Baum, R. B., Savage, W. Z., Salciarini, D., Schulz, W. H., and Harp, E. L.: Transient deterministic shallow landslide modeling: Requirements for susceptibility and hazard assessments in a GIS framework, Eng. Geol., 102, 214-226,

102008.

Hsu, S. M., Wen, H. Y., Chen, N. C., Hsu, S. Y., and Chi, S. Y.: Using an integrated method to estimate watershed sediment yield during heavy rain period: a case study in Hualien County, Taiwan, Nat. Hazards Earth Syst. Sci., 12, $1949-1960,2012$. Hsu, H. H., Chou, C., Wu, Y. C., Lu, M. M., Chen, C. T., and Chen, Y. M.: Climate Change in Taiwan: Scientific Report 2011 (Summary), National Science Council, Taipei, Taiwan, 2011.

15 Huang, J. C., and Kao, S. J.: Optimal estimator for assessing landslide model performance, Hydrology Earth Syst., 10, 957$965,2006$.

Hungr, O.: A model for the runout analysis of rapid flow slide, debris flow, and avalanches, Canadian Geotechnical Journal, $32,610-623,1995$.

Hutter, K., and Greve, R.: Two-dimensional similarity solutions for finite-mass granular avalanches with Coulomb- and

20 viscous-type frictional resistance, J. Glaciol., 39, 357-372, 1993.

IPCC: Summary for Policymakers. In: Managing the Risks of Extreme Events and Disasters to Advance Climate Change Adaptation. In: Field, C. B., Barros, V., and Stocker, T. F. et al. (ed) A Special Report of Working Groups I and II of the Intergovernmental Panel on Climate Change. Cambridge University Press, Cambridge, UK, and New York, NY, USA, 1-19, 2012.

25 IPCC: Climate Change 2013: The Physical Science Basis. Contribution of Working Group I to the Fifth Assessment Report of the Intergovernmental Panel on Climate Change [Stocker, T.F., D. Qin, G.-K. Plattner, M. Tignor, S.K. Allen, J. Boschung, A. Nauels, Y. Xia, V. Bex and P.M. Midgley (eds.)]. Cambridge University Press, Cambridge, United Kingdom and New York, NY, USA, 1535 pp, 2013.

Iverson, R. M.: The physics of debris flows, Rev. Geophys. 35 (3), 245-296, 1997.

30 Iverson, R. M.: Landslid triggering by rain infiltration, Water Resour. Res., 36, 1897-1910, 2000.

Julien, P. Y., and Lan, Y.: Rheology of Hyperconcentrations, J. Hydraul. Eng., 117(3), 346-353, 1991.

Khazai, B., and Sitar, N.: Companion website for landslides in Native Ground: A GIS-Based Approach to Regional Seismic Stability Slope Stability Assessment. http://www2.ced.berkeley.edu:8002/index2.html, 2000. 
Nat. Hazards Earth Syst. Sci. Discuss., https://doi.org/10.5194/nhess-2017-262

Manuscript under review for journal Nat. Hazards Earth Syst. Sci.

Discussion started: 21 August 2017

(c) Author(s) 2017. CC BY 4.0 License.
Natural Hazards

and Earth System

Sciences

Discussions

\section{(c) (i)}

Li, H. C., Wu, T., Wei, S. P., Shih, H. J., and Chao, Y. C.: Basinwide disaster loss assessments under extreme climate scenarios: a case study of the Kaoping River basin, Nat Hazards, 86:1039-1058, 2017.

Liu, K. F., and Huang, M. C.: Numerical simulation of debris flow with application on hazard area mapping, Computational Geoscience, 10, 221-240, 2006.

5 Liu, K. F., Li, H. C., and Hsu, Y. C.: Debris flow hazard assessment with numerical simulation, Natural Hazards, 49, 137-161, 2009.

Liu, K. F., Wu, Y. H., Chen, Y. C., Chiu, Y. J., and Shih, S. S.: Large scale simulation of watershed mass ransport-A case study of TsengWen watershed, Natural Hazards, 67(2), 855-867, 2013.

Mizuta, R., Yoshimura, H., Murakami, H., Matsueda, M., Endo, H., Ose, T., Kamiguchi, K., Hosaka, M., Sugi, M., Yukimoto,

10 S., Kusunoki, S., and Kitoh, A.: Climate simulations using MRI-AGCM3.2 with 20-km grid, J. Meteorol. Soc. Jpn, 90A, 233$258,2012$.

Montgomery, D. R., and Dietrich, W. E.: A physically based model for topographic control on shallow landsliding, Water Resources Research, 30, 1153-1171, 1994.

Nakatani, K., Wada, T., Satofuka, Y., and Mizuyama, T.: Development of “Kanako 2D (Ver.2.00)," a user-friendly one- and

15 two-dimensional debris flow simulator equipped with a graphical user interface, International Journal of Erosion Control Engineering, 1(2), 62-72, 2008.

National Science and Technology Center for Disaster Reduction: Sediment Disasters Impact Assessment in Slopeland, National Science and Technology Center for Disaster Reduction, Taiwan: NCDR 100-T36, 2011.

O’Brien, J. S., Julien, P. Y., and Fullerton, W. T.: Two-dimensional water flood and mudflow simulation, J. Hydraul. Eng., 20 119, 244-259, 1993.

Park, D. W., Nikhil, N. V., and Lee, S. R.: Landslide and debris flow susceptibility zonation using TRIGRS for the 2011 Seoul landslide event, Nat. Hazards Earth Syst. Sci., 13, 2833-2849, 2013.

Rebetez, M., Lugon, R., and Baeriswyl, P. A.: Climatic change and debris flows in high mountain regions: The case study of the Ritigraben torrent (Swiss Alps), Climatic Change, 36(3-4), 371-389, 1997.

25 Sassa, K., Wang, G., Fukuoka, H., Wang, F. W., Ochiai, T., Sugiyama, M., and Sekiguchi, T.: Landslide risk evaluation and hazard mapping for rapid and long-travel landslides in urban development areas, Landslides, 1(3), $221-235,2004$.

Salciarini, D., Godt, J. W., Savage, W. Z., Conversini, P., Baum, R. L., and Michael, J. A.: Modeling regional initiation of rainfall-induced shallow landslides in the eastern Umbria Region of central Italy, Landslides, 3, 181-197, 2006.

Skamarock, W., Klemp, J. B., Dudhia, J., Gill, D. O., Barker, D., Duda, M. G., Huang, X. Y., and Wang, W.: A description of

30 the Advanced Research WRF version 3, NCAR Technical Note NCAR/TN-475 + STR, doi:10.5065/D68S4MVH, 2008.

Stoffel, M., Mendlik, T., Schneuwly-Bollschweiler, M., and Gobiet, A.: Possible impacts of climate change on debris-flow activity in the Swiss Alps, Climatic Change, 122, 141-155, 2014. 
Nat. Hazards Earth Syst. Sci. Discuss., https://doi.org/10.5194/nhess-2017-262

Manuscript under review for journal Nat. Hazards Earth Syst. Sci.

Discussion started: 21 August 2017

(c) Author(s) 2017. CC BY 4.0 License.

(c) (i)

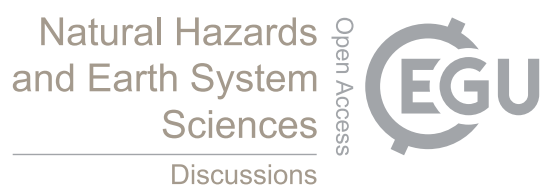

Shih, H. J., Wu, T., Su, Y. F., Liu, C. H., Li, H. C., Chen, Y. M., and Chang, C. H.: Shallow Landslide Disaster Impact Assessment under Extreme Rainfall Event in the Climate Change Scenario, Journal of Engineering Environment, 34, 77-96, 2015.

Su, Y. F., Cheng, C. T., Liou, J. J., Chen, Y. M., and Kitoh, A.: Bias correction of MRI-WRF dynamic downscaling datasets, 5 Terr. Atmos. Ocean. Sci., 27, 649-657, 2016.

Takahashi, T.: Debris flow, Annual Review Fluid Mechanics, 13, 57-77, 1981.

Tsai, M. P., Hsu, Y. C., Li, H. C., and Liu, K. F.: Application of simulation technique on debris flow hazard zone delineation: a case study in the Daniao tribe, Eastern Taiwan, Nat. Hazards Earth Syst. Sci., 11, 3053-3062, 2011.

Wei, L. W., Huang, W. K., Huang, C. M., Lee, C. F., Lin, S. C., and Chi, C. C.: The Mechanism of Landslides Caused by

10 Typhoon Soudelor in Northern Taiwan, Journal of Chinese Soil and Water Conservation, 46(4), 223-232, 2015.

Wu, T., Li, H. C., Wei, S. P., Chen, W. B., Chen, Y. M., Su, Y. F., Liu, J. J., and Shih, H. J.: A comprehensive disaster impact assessment of extreme rainfall events under climate change: a case study in Zheng-wen river basin, Taiwan, Environ Earth Sci., 75, 597, 2016.

Wu, T., Jang, J. H., Liu, C. H., Shih, H. J., and Chang, C. H.: Sediment Disaster Impact and Effect Assessment Induced by

15 Extreme Rainfall in Xin-Dian River Basin, Journal of Disaster Management, 5(2), 19-39, 2016.

Wu, Y. H., Liu, K. F., and Chen, Y. C.: Comparison between FLO-2D and Debris-2D on the application of assessment of granular debris flow hazards with case study, J. Mt. Sci., 10(2), 293-304, 2013. 
Nat. Hazards Earth Syst. Sci. Discuss., https://doi.org/10.5194/nhess-2017-262

Manuscript under review for journal Nat. Hazards Earth Syst. Sci.

Discussion started: 21 August 2017

(C) Author(s) 2017. CC BY 4.0 License.

(c) (i)

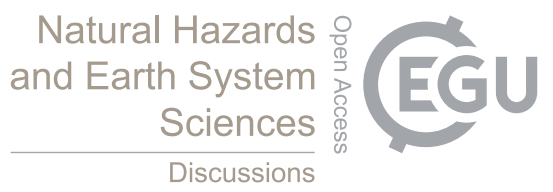

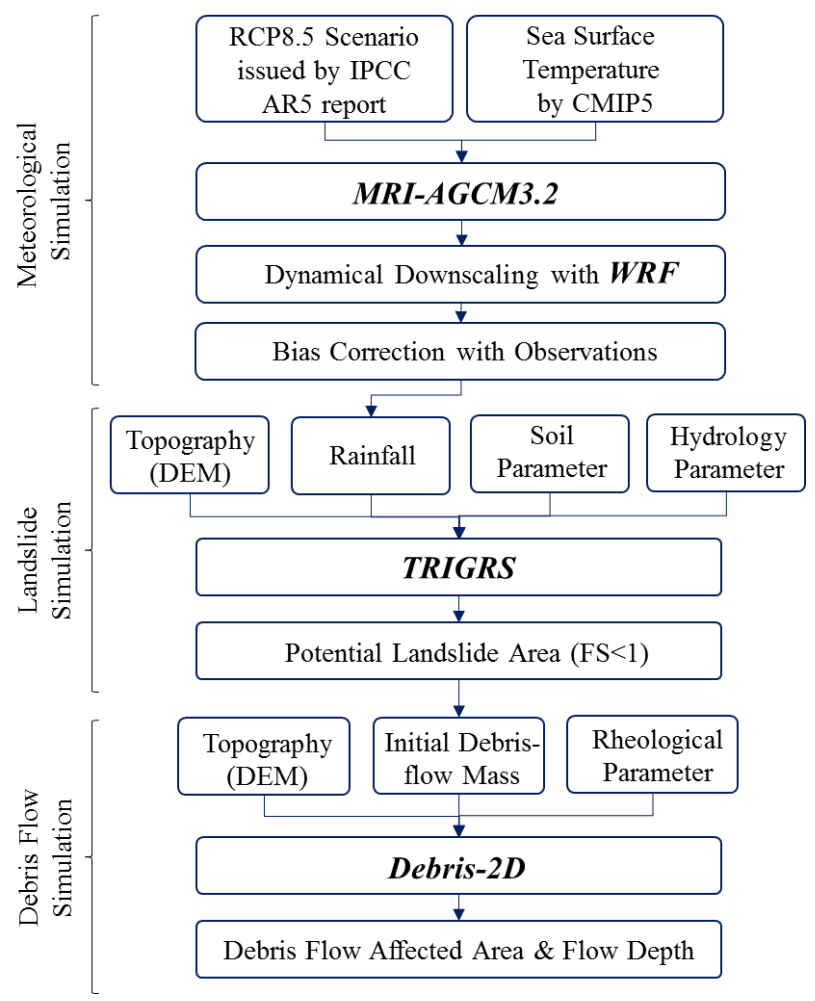

Figure 1: Integrated Simulation Process. 
Nat. Hazards Earth Syst. Sci. Discuss., https://doi.org/10.5194/nhess-2017-262

Manuscript under review for journal Nat. Hazards Earth Syst. Sci.

Discussion started: 21 August 2017

(c) Author(s) 2017. CC BY 4.0 License.

\section{Natural Hazards and Earth System Sciences \\ Discussions}

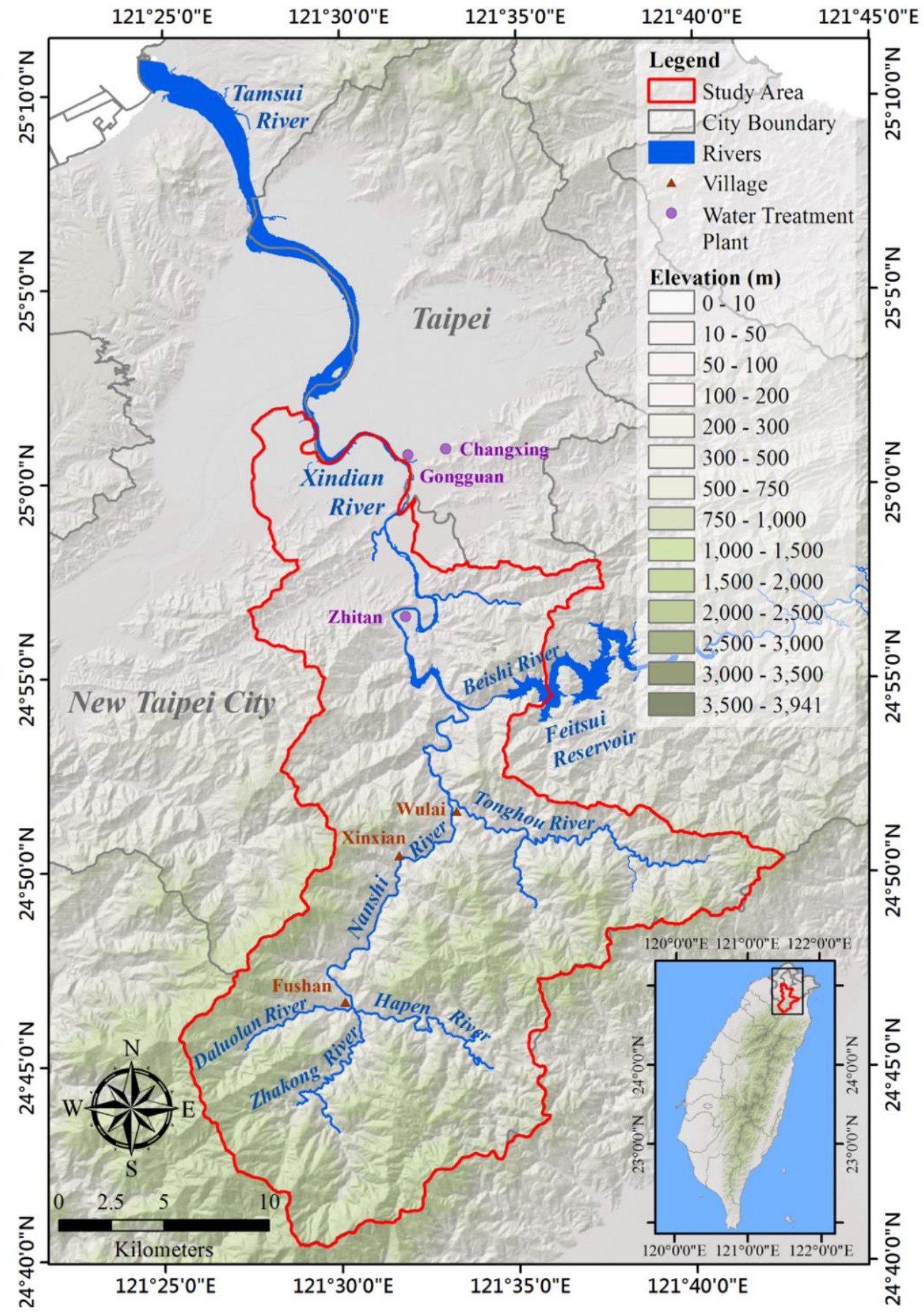

Figure 2: Topography (shaded relief) and location of Study Area 
Nat. Hazards Earth Syst. Sci. Discuss., https://doi.org/10.5194/nhess-2017-262

Manuscript under review for journal Nat. Hazards Earth Syst. Sci.

Discussion started: 21 August 2017

(c) Author(s) 2017. CC BY 4.0 License. a.

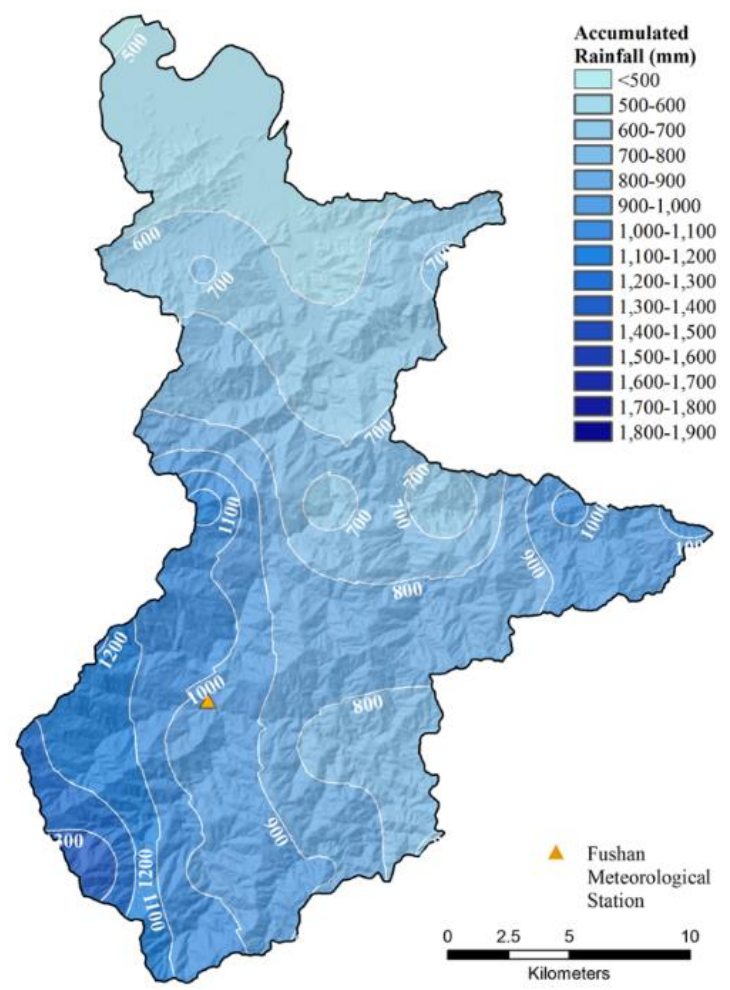

b.

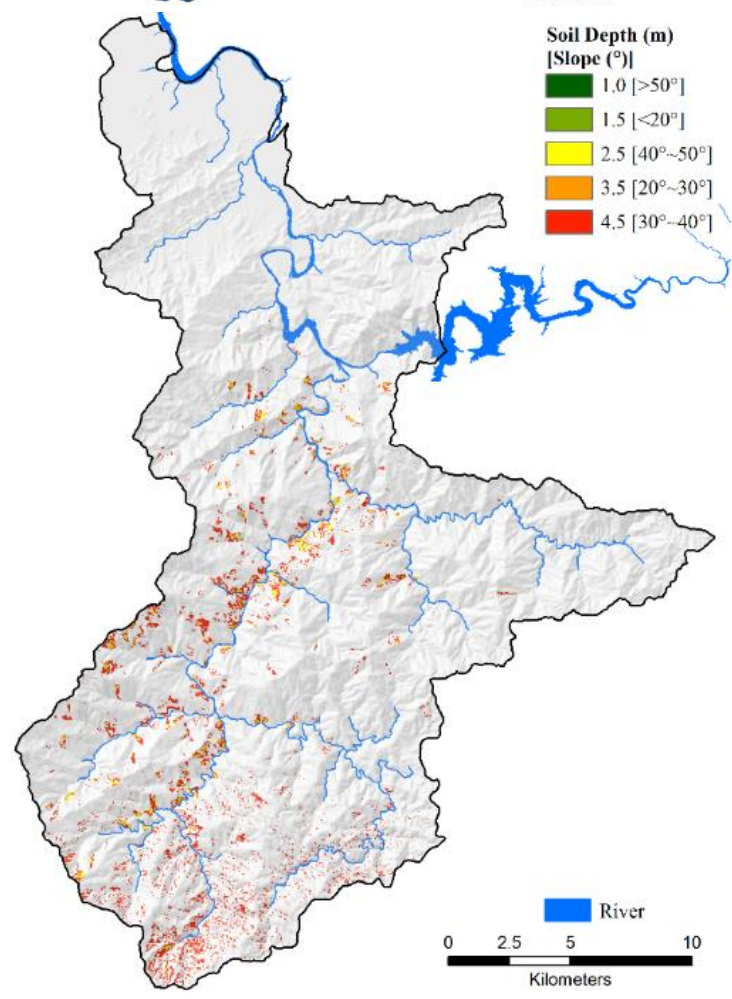

Natural Hazards 윰 and Earth System Sciences

Discussions

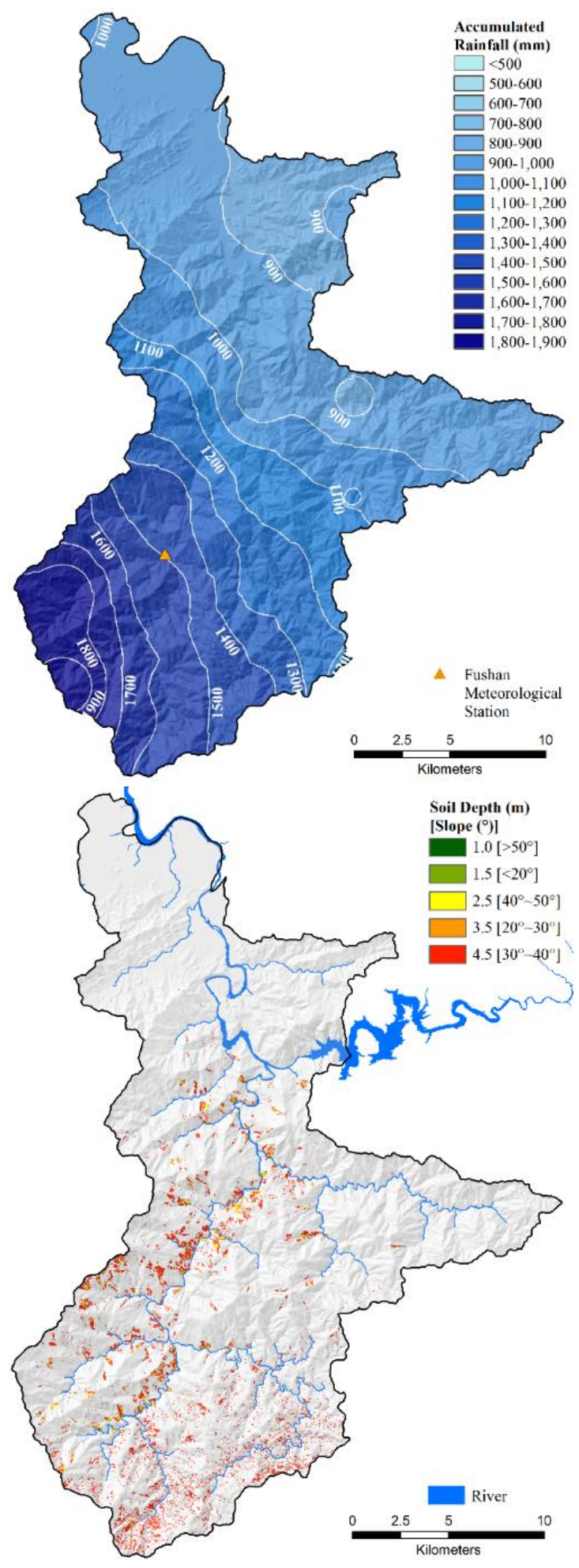


Nat. Hazards Earth Syst. Sci. Discuss., https://doi.org/10.5194/nhess-2017-262

Manuscript under review for journal Nat. Hazards Earth Syst. Sci.

Discussion started: 21 August 2017

(c) Author(s) 2017. CC BY 4.0 License.

(c) (i)

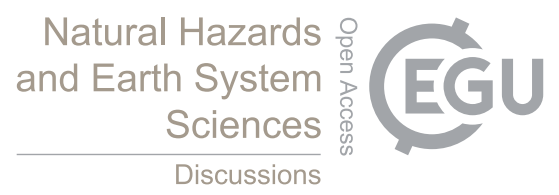

c.

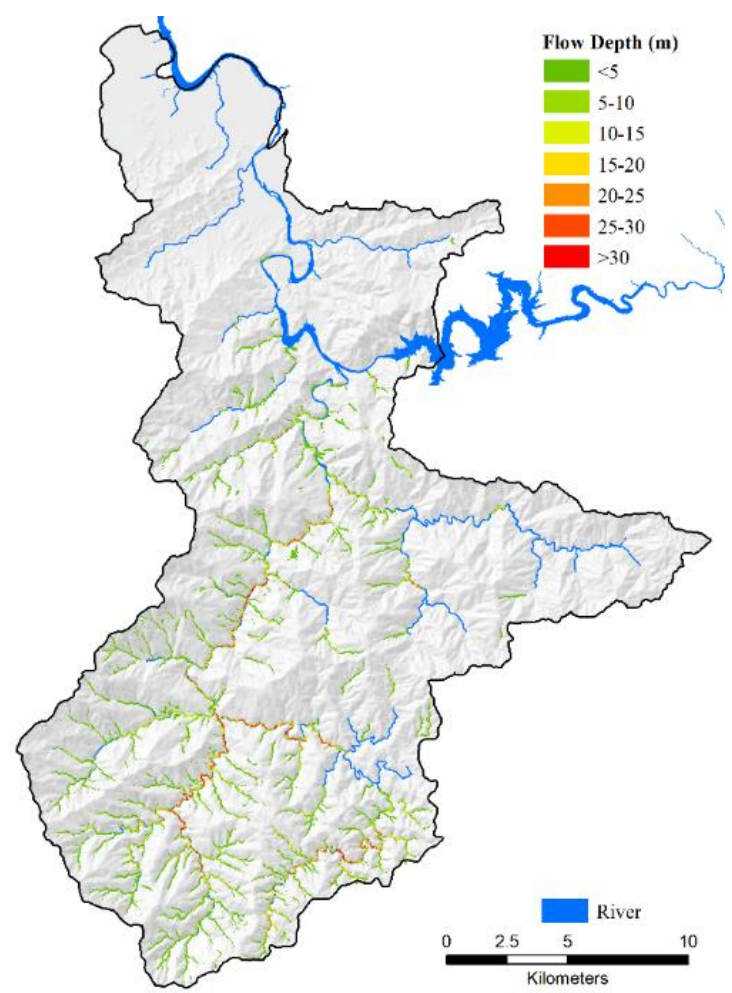

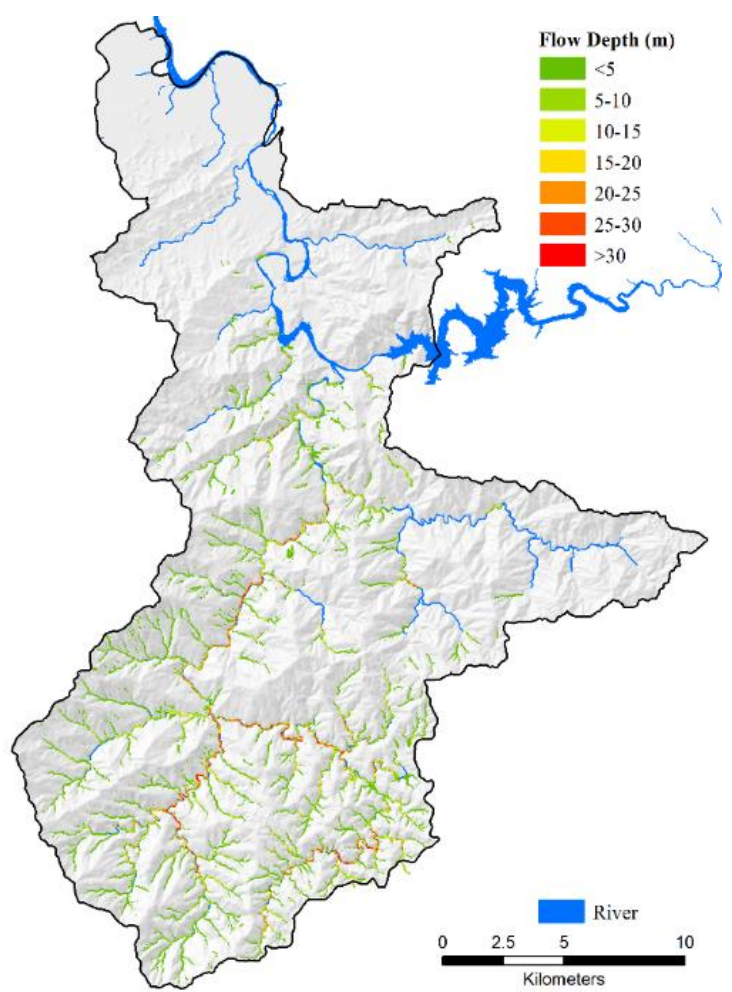

Figure 3: Simulation Results. a. Accumulated rainfall distribution; b. Potential landslide area; c. The final flow depth of debris flow; the left and right figures are scenario 1 and scenario 2, respectively. 
Nat. Hazards Earth Syst. Sci. Discuss., https://doi.org/10.5194/nhess-2017-262

Manuscript under review for journal Nat. Hazards Earth Syst. Sci.

Discussion started: 21 August 2017

(c) Author(s) 2017. CC BY 4.0 License.
Natural Hazards and Earth System Sciences

Discussions (c) (i)
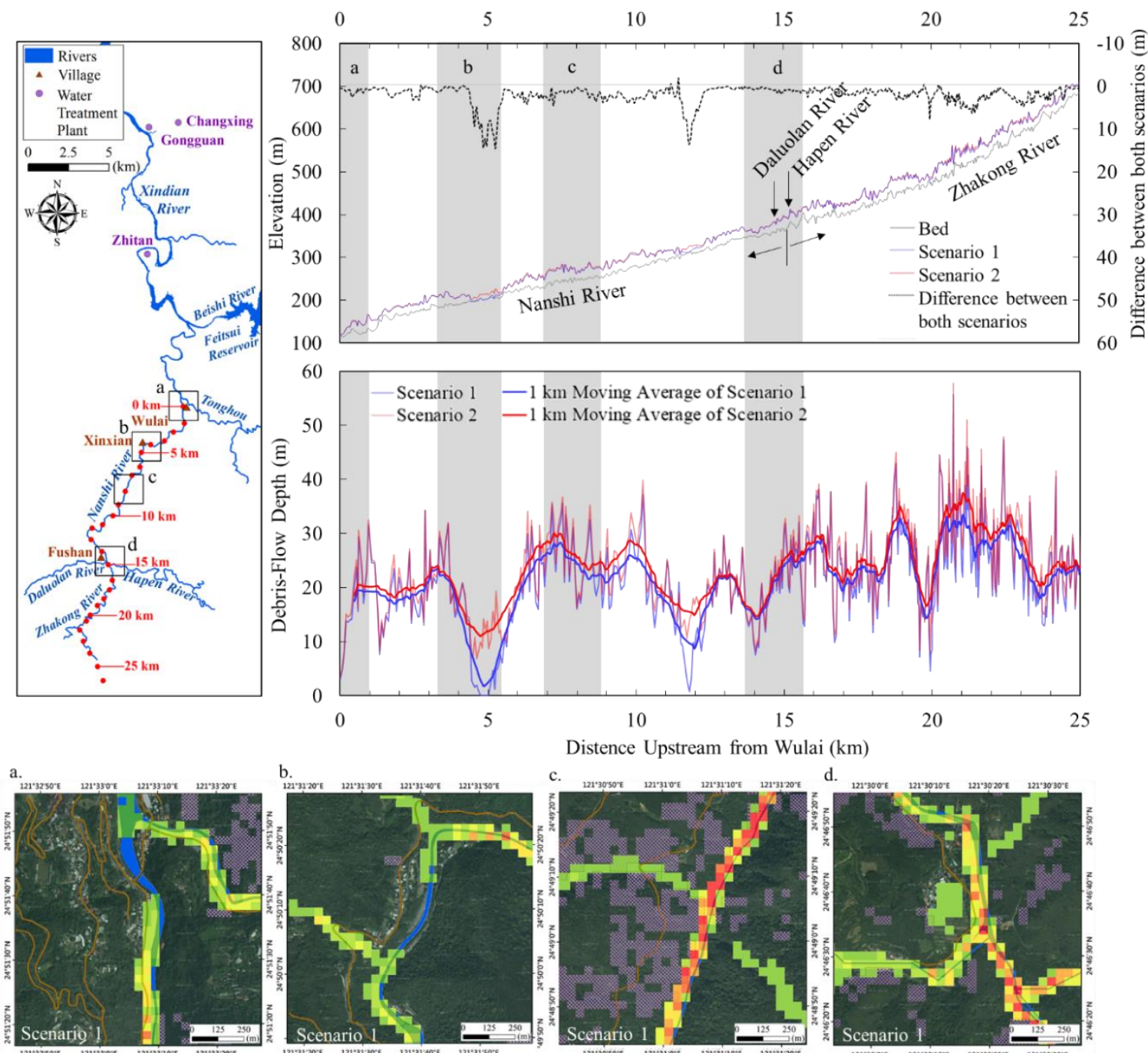

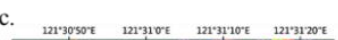
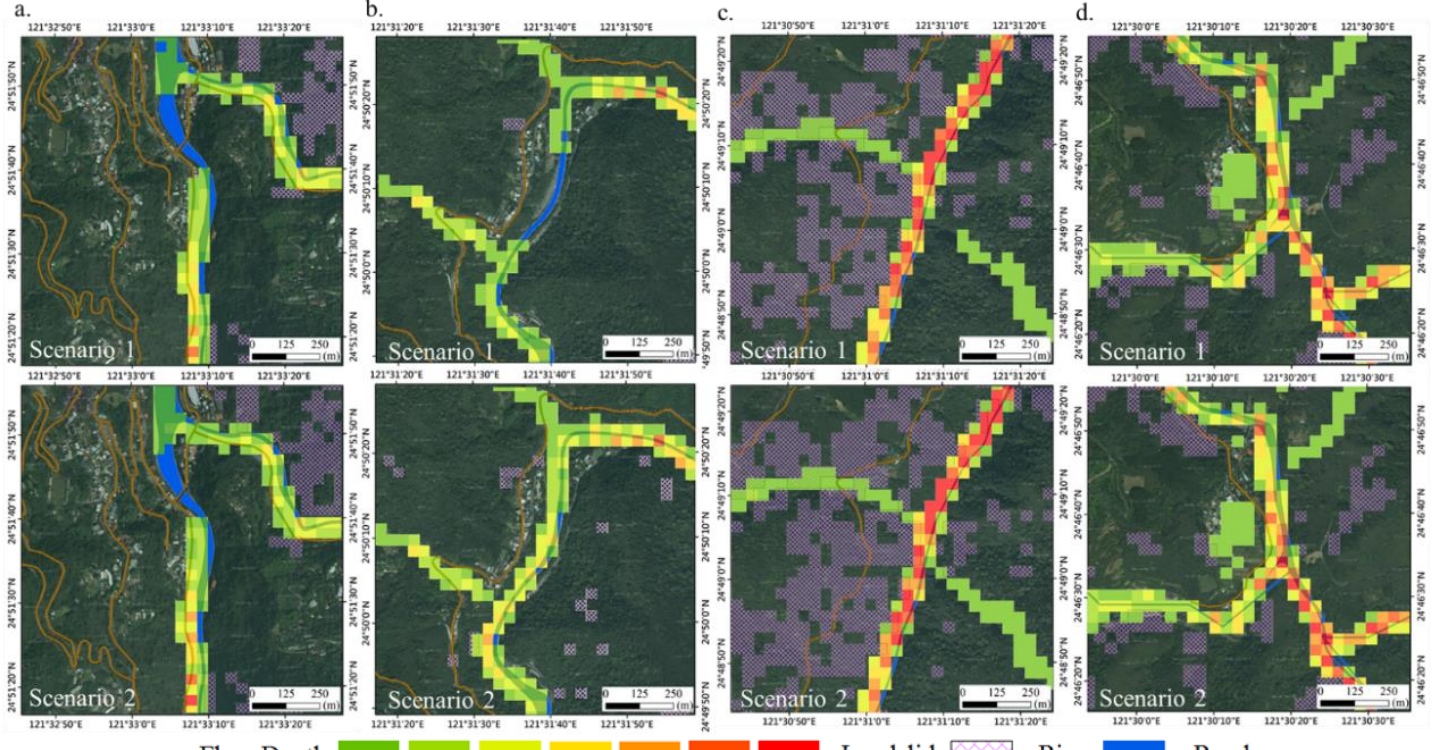

$(\mathrm{m})$
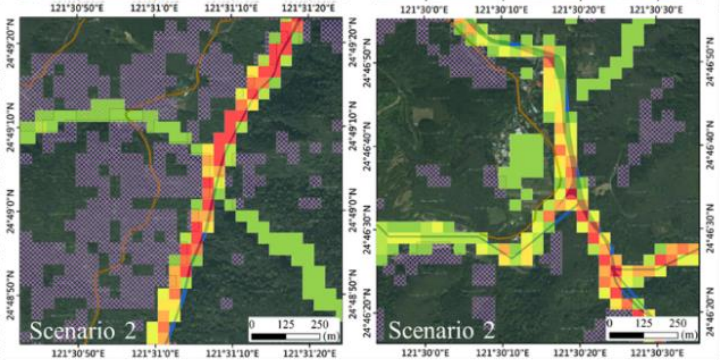

Landslide

River

Roads $=$

Figure 4: Longitudinal profiles of debris-flow accumulation along river and its corresponding aerial photos in different regions; the reach of profile in top right figure are along the red dots with $1 \mathrm{~km}$ interval in top left figure. The black windows in top left figure are region of interest. The simulation results in each windows are highlighted by gray background in top right figure and shown in below figure with aerial photos provided by National Land Surveying and Mapping Center (NLSC), Taiwan. 
Nat. Hazards Earth Syst. Sci. Discuss., https://doi.org/10.5194/nhess-2017-262

Manuscript under review for journal Nat. Hazards Earth Syst. Sci.

Discussion started: 21 August 2017

(C) Author(s) 2017. CC BY 4.0 License.
Natural Hazards 을 and Earth System Sciences

Discussions (c) (1)

Table 1 The parameters used in TRIGRS

\begin{tabular}{|c|c|c|c|c|c|c|c|}
\hline $\begin{array}{c}\text { Geologic } \\
\text { Time }\end{array}$ & Name (abbr.) & $\begin{array}{c}C \\
(\mathbf{k P a})\end{array}$ & $\begin{array}{l}\phi \\
\left({ }^{\circ}\right)\end{array}$ & $\begin{array}{c}\gamma_{s} \\
\left(\mathbf{k N} / \mathbf{m}^{3}\right)\end{array}$ & $\begin{array}{c}K_{S} \\
\left(10^{-6} \mathrm{~m} / \mathrm{s}\right)\end{array}$ & $\begin{array}{c}D_{0} \\
\left(10^{-6} \mathrm{~m}^{2} / \mathrm{s}\right)\end{array}$ & $\begin{array}{c}\text { Description (Ref: Central } \\
\text { Geological Survey in Taiwan) }\end{array}$ \\
\hline \multirow[b]{2}{*}{ Holocene } & Alluvium (a) & 10.5 & 34 & 19.5 & 29 & 8800 & Gravel, sand, and mud \\
\hline & $\begin{array}{l}\text { Terrace Deposits } \\
\text { (t) }\end{array}$ & 6.5 & 30 & 23 & 0.7 & 220 & Gravel, sand and clay \\
\hline Pleistocene & $\begin{array}{l}\text { Lateritic Terrace } \\
\text { Deposits (lt) }\end{array}$ & 35 & 30 & 18.6 & 0.8 & 800 & $\begin{array}{l}\text { Red earth, lateritic gravel, sand, } \\
\text { intercalated with sand and silt } \\
\text { lentils }\end{array}$ \\
\hline \multirow{7}{*}{ Miocene } & $\begin{array}{l}\text { Mushan } \\
\text { Formation (Ms) }\end{array}$ & $\begin{array}{l}16.8- \\
28.8\end{array}$ & $\begin{array}{l}32.0- \\
36.0\end{array}$ & 27.5 & 10 & 2000 & $\begin{array}{l}\text { Alternations of sandstone and shale, } \\
\text { intercalated with coal seams }\end{array}$ \\
\hline & $\begin{array}{l}\text { Nanchuang } \\
\text { Formation }(\mathrm{Nc})\end{array}$ & 23.5 & 34.5 & 27.5 & 10 & 2000 & $\begin{array}{l}\text { Alternations of sandstone and shale, } \\
\text { intercalated with coal seams }\end{array}$ \\
\hline & $\begin{array}{l}\text { Nankang } \\
\text { Formation }(\mathrm{Nk})\end{array}$ & 29 & 36 & 27.5 & 10 & 2000 & Sandstone, siltstone, and shale \\
\hline & Piling Shale (Pi) & $\begin{array}{l}19.9- \\
27.4\end{array}$ & $\begin{array}{l}32.0- \\
35.0\end{array}$ & 24.8 & 10 & 2000 & Shale with intercalated sandstone \\
\hline & $\begin{array}{l}\text { Shihti Formation } \\
\text { (St) }\end{array}$ & $\begin{array}{l}24.1- \\
30.1\end{array}$ & $\begin{array}{c}32.0- \\
34.0\end{array}$ & 27.5 & 10 & 2000 & $\begin{array}{l}\text { Alternations of sandstone and shale, } \\
\text { intercalated with coal seams }\end{array}$ \\
\hline & $\begin{array}{ll}\text { Tapu } & \text { Formation } \\
(\mathrm{Tp}) & \\
\end{array}$ & 20.9 & 34 & 27.5 & 10 & 2000 & $\begin{array}{l}\text { Alternations of muddy sandstone, } \\
\text { white sandstone and shale }\end{array}$ \\
\hline & $\begin{array}{l}\text { Taliao Formation } \\
(\mathrm{Tl})\end{array}$ & $\begin{array}{l}16.3- \\
27.3\end{array}$ & $\begin{array}{l}32.0- \\
36.0\end{array}$ & 27.5 & 10 & 2000 & Shale and sandstone \\
\hline $\begin{array}{l}\text { Oligocene- } \\
\text { Miocene }\end{array}$ & $\begin{array}{l}\text { Wenshui } \\
\text { Formation (Ws) }\end{array}$ & $\begin{array}{l}16.4- \\
28.9\end{array}$ & $\begin{array}{l}32.0- \\
36.0\end{array}$ & 24.8 & 10 & 2000 & Sandstone and shale interbeds \\
\hline \multirow{4}{*}{ Oligocene } & $\begin{array}{l}\text { Kangkou } \\
\text { Formation (Kk) }\end{array}$ & $\begin{array}{l}20.6- \\
33.1\end{array}$ & $\begin{array}{l}26.0- \\
31.5\end{array}$ & 25.3 & 20 & 4000 & $\begin{array}{l}\text { Argillite or slate intercalated with } \\
\text { thin to thick-bedded siltstone }\end{array}$ \\
\hline & $\begin{array}{l}\text { Shuichangliu } \\
\text { Formation }(\mathrm{Om}) \\
\end{array}$ & $\begin{array}{l}21.0- \\
33.5\end{array}$ & $\begin{array}{l}29.0- \\
33.0\end{array}$ & 27.5 & 10 & 2000 & Argillite, slate \\
\hline & $\begin{array}{l}\text { Tatungshan } \\
\text { Formation }(\mathrm{Tt})\end{array}$ & $\begin{array}{l}19.1- \\
33.0\end{array}$ & $\begin{array}{l}28.0- \\
34.0\end{array}$ & 27.5 & 10 & 2000 & $\begin{array}{l}\text { Argillite intercalated with thin to } \\
\text { thick-bedded siltstone and fine- } \\
\text { grained sandstone }\end{array}$ \\
\hline & $\begin{array}{l}\text { Tsuku Formation } \\
(\mathrm{Tu})\end{array}$ & $\begin{array}{l}18.0- \\
30.0\end{array}$ & $\begin{array}{l}27.0- \\
30.0\end{array}$ & 25.3 & 10 & 1000 & Alternations of siltstone and argillite \\
\hline \multirow{3}{*}{ Eocene } & $\begin{array}{l}\text { Chungling } \\
\text { Formation }(\mathrm{Cl})\end{array}$ & $\begin{array}{l}24.8- \\
32.8\end{array}$ & 29 & 25 & 20 & 4000 & $\begin{array}{l}\text { Argillite or slate, with thin bedded } \\
\text { metasandstone }\end{array}$ \\
\hline & $\begin{array}{l}\text { Hsitsun } \\
\text { Formation }(\mathrm{Ht})\end{array}$ & $\begin{array}{l}22.2- \\
32.6\end{array}$ & $\begin{array}{l}30.5- \\
33.5\end{array}$ & 25 & 10 & 2000 & $\begin{array}{l}\text { Thin alternations of argillite and } \\
\text { metasandstone }\end{array}$ \\
\hline & $\begin{array}{l}\text { Szeleng } \\
\text { Sandstone (Em) }\end{array}$ & $\begin{array}{l}18.1- \\
32.0\end{array}$ & $\begin{array}{l}28.0- \\
32.0\end{array}$ & 23.5 & 10 & 2000 & $\begin{array}{l}\text { Thick-bedded party pebbly quartzitic } \\
\text { sandstone, arkosic sandstone and } \\
\text { thin alternations, with argillite and } \\
\text { thin coal seams on the upper part }\end{array}$ \\
\hline
\end{tabular}

Remarks: The $C, \phi, \gamma_{s}$ are calibrated from 2008 to 2012 with $M S R=88 \%, 87 \%, 84 \%, 84 \%$, and 86\%, and verified by Typhoon Soudelor in 2015 with $M S R=91 \%$. The representative rainfall events used for calibration are Typhoon Kalmaegi, Typhoon Jangmi, and Typhoon Sinlaku in 2008; Typhoon Parma and Typhoon Morakot in 2009; Typhoon Megi and Typhoon Fanapi in 2010; Typhoon Nanmadol and 1001 Rainfall in 2011; Typhoon Saola in 2012. The $K_{S}$, and $D_{0}$ are cited from past investigation (Central Geological Survey 2010) 